\title{
Bald Eagles and Forest Management
}

\author{
by
}

Robert J. Anderson 1

\begin{abstract}
Current management of known bald eagle nesting habitat on Weyerhaeuser Company lands in Oregon and Washington states is described. Observations of continued nesting productivity indicate that with careful planning successful integration of forest and eagle habitat management is achievable. Forest management programs can provide nesting habitat concurrent with the production of forest products by manipulation of forest stand structure using site-specific management plans. Factors to be considered in maintaining suitable nesting habitat relate to the specific location and prominence of the area relative to the surroundings and tree crown conditions within areas of potential eagle use. Management for nesting habitat must be directed towards the entire potential nesting site, rather than at individual nest trees for maintenance of successful eagle nesting.
\end{abstract}

Key words: Bald eagle, wildlife management, forest management, endangered species.

\section{Introduction}

The management of bald eagle (Haliaeetus leucocephalus) habitat within commercial forest lands often is perceived as a conflict between two important resource management objectives. The loss of nesting habitat due to human settlement, uninformed forest management, shooting, electrocution, and pesticide contamination is the cause of declining bald eagle numbers (Lincer et al. 1979). The nature and timing of forest management practices conducted within eagle nesting areas often generates legitimate concerns for the continued wellbeing of the American national bird. International treaties; and US federal laws ${ }^{2}$ provide direct protection to eagles, their nests and eggs but few incentives other than recognition of a social responsibility provide for the protection or management of eagle habitat on private lands.

Over the past 14 years, the knowledge gained on habitat requirements of these birds, on the effects of silvicultural practices in shaping forest stand structure, and on the response by nesting eagles provides useful insight into the compatibility between forest and eagle management.

'Wildlife Research Biologist, Weyerhaeuser Company, Technology Center, Tacoma, Washington 98477

2Migratory Bird Treaty Act, as amended, 16 U.S.C. 703-711 and Bald and Golden Eagle Protection Act, as amended, 16 U.S.C. $668-668 \mathrm{~d}$
A nesting territory or site is the area used by one pair of eagles and may contain several nests, occurs in various forest types and conditions and is located near an abundant source of food (Snow 1973). As many as five nests within a single nesting site have been reported, where any one nest may be used annually, although not consistently, by one pair of eagles (Chrest 1964). Tree nests have been reported to last for over 35 years (Herrick 1924) and have an average longevity of 9 years (Mattsson and Grewe 1976) depending upon the tree species, shape of the crown, weight of the nest, and local weather patterns. Although characteristics of habitat within nesting sites have not been well described, forest conditions in the immediate vicinity of individual nest trees are documented for southeast Alaska (Corr 1974), the Pacific Northwest (Anthony et al. 1982), and California (Lehman 1980). Similar descriptions are available for Yellowstone Park (Swensen 1975), Minnesota (Fraser 1981), Florida (McEwan and Hirth 1979), Saskatchewan and Manitoba (Whitfield et al. 1974), and New Brunswick (Stocek and Pearce 1981). Although some of these studies suggest mature coniferous forest stands are necessary as nesting areas, nesting occurs under a wide variety of conditions. Active bald eagle nests have been found on open ground, cliffs and rock pinnacles, tops of shrubs, in a variety of deciduous and coniferous tree species, and on artificial structures specifically developed for the birds (Grubb 1980). Nesting trees occur as isolated, single trees and in continuous forest stands. Generally, tree nests are located in prominent areas near an abundant water-based source of food, and in trees with adequate strength to support the size and weight of the nest.

The effects of human activities on eagle behavior and nesting success are the subject of recent studies. Mathisen (1968) reported no differences in nesting success when he rated nests by degree of isolation from human activity. Modifications in nesting areas by forest management "did not appear to affect nesting activity." Lehman (1980) suggested that birds nested further from shoreline feeding areas along water bodies with heavy recreational use, presumably because of disturbance. Young (1980) described what appeared to be an adjustment by the birds in the timing of activities at nests located near heavy public-use areas. With the possibility of behavioral adjustments by breeding eagles, an increase in the number of nesting birds was reported in areas of substantial housing development and recreational use (Newman et al. 1977). Thus, the tolerance of particular pairs of birds to different types of human activity is apparently highly variable.

Based on knowledge of habitat conditions and the responses of eagles to various human activities, management 
guidelines (USDI Fish and Wildlife Service 1981) have been developed to protect nest trees from direct harm and limit the effects of disturbance on nesting birds. These guidelines, currently used by several land management and regulatory agencies as minimum requirements for habitat protection, suggest two zones be delineated around nest trees where land management and public-use activities be restricted. In the zone nearest the nest, prohibition of all activities is recommended so that a vegetative buffer exists to limit public and eagle visibility, provide perch trees, and give physical protection to the nest tree. This zone should have a minimum radius of 100 m or a 10 ha tract where hazard from windthrow is high. The second zone is to be established during the active nesting season only and lies outside the first zone to give further protection against disturbance. This second buffer has a minimum radius of $200 \mathrm{~m}$ in the northwest United States and over $1600 \mathrm{~m}$ in the southeast United States (USDI Fish and Wild life Service, no date). The Northern States Bald Eagle Recovery Plan (USDI Fish and Wildlife Service 1983) suggests that restrictions in land management activities during nesting be coordinated with differing degrees of sensitivity of eagles, with the "most critical" period at the time of nest establishment and pair bonding and the "least critical" time when eaglets are near fledging. Management guidelines also suggest providing opportunities for future nesting by delineating areas of potential eagle use, each of which is a minimum of 20 ha where all land management activities are restricted (USDI Fish and Wildlife Service 1981).

Studies cited above indicate that eagles nest successfully in a wide variety of habitat conditions and in conjunction with varying levels of human activity and land management practi- ces. Because of this variation, it is not possible to prepare a specific prescription that applies to all eagle nesting habitat. The objectives of this paper are to report our observations of nesting eagles on Weyerhaeuser Company lands relative to forest management activities, and to provide additional insights into eagle habitat management using site-specific approaches as opposed to adherence to published guidelines (USDI Fish and Wildlife Service 1981).

\section{Procedures}

From 1970 to the present, we have observed forest management and eagle nesting activities on Weyerhaeuser Company land in Oregon and Washington states. Nests occur in the ponderosa pine (Pinus ponderosa) and mixed conifer (Pseudotsuga, Pinus, Libocedrus, Abies) forest types of southcentral Oregon and in the Douglas-fir (Pseudotsuga menziesii) - western hemlock (Tsuga heterophylla) forest type of western Oregon and Washington. Nests are recorded, described and grouped into nesting sites based primarily upon their proximity to other nests and nesting history of the area. Termination for nesting productivity follows Postupalsky (1974).

All known forest management activities conducted within $1 \mathrm{~km}$ of any nest are documented. Silvicultural practices vary by forest type, with differing degrees of selective harvest common in pine and mixed conifer management. Clearcutting is the standard harvest method in the Douglas-fir forest type. Forest management activities are restricted during the nesting period in areas containing breeding birds. Following prevailing eagle management practices, retaining single nest trees was common until the late 1960s after which three to five perch

Table 1. Nesting success at eagle nesting sites in the pine region at southcentral Oregan. Logging activity is indicated by ${ }^{*} .0$ is a nest failure; 1,2 or 3 is a nesting success and the number of eaglets fledged; - is a symbol for inactive classification; $X$ means that no nest currently exists.

\begin{tabular}{|c|c|c|c|c|c|c|c|c|c|c|c|c|c|c|}
\hline \multirow{2}{*}{$\begin{array}{l}\text { Nesting site } \\
\text { (number of nests) }\end{array}$} & \multicolumn{14}{|c|}{ Year } \\
\hline & 1971 & 72 & 73 & 74 & 75 & 76 & 77 & 78 & 79 & 80 & 81 & 82 & 83 & 84 \\
\hline $1(9)$ & ${ }^{*} 0$ & - & 2 & 2 & 1 & - & 1 & 2 & 1 & 1 & 2 & 1 & 1 & $\overline{1}$ \\
\hline $2(1)$ & $*$ & - & 0 & 0 & - & - & - & - & - & - & - & - & - & 0 \\
\hline $3(5)$ & *- & - & - & 0 & - & 0 & - & - & - & - & - & - & - & - \\
\hline $4(2)$ & $* 1$ & 1 & - & 0 & - & 0 & - & - & 0 & - & - & 0 & 0 & 0 \\
\hline $5(4)$ & *2 & 0 & - & 0 & - & 1 & 0 & 0 & 2 & 0 & 1 & 0 & 2 & 0 \\
\hline $6(2)$ & $* 1$ & 1 & 1 & - & - & 0 & - & - & 0 & - & 0 & - & - & - \\
\hline $7(2)$ & *- & - & - & - & - & . & - & - & - & - & - & - & - & - \\
\hline $8(4)$ & 0 & - & ${ }^{*}$ & 2 & 0 & - & - & - & - & 0 & 0 & D & 0 & 0 \\
\hline $9(5)$ & 1 & - & 1 & 1 & - & 1 & 1 & 1 & 1 & 0 & ${ }^{*} 0$ & 2 & 1 & 1 \\
\hline $10(3)$ & $*$ & - & - & 0 & - & - & - & 1 & 0 & 0 & - & 1 & 2 & 0 \\
\hline $11(4)$ & - & - & - & ${ }^{\circ} 0$ & - & - & 0 & - & 1 & 2 & - & 1 & 2 & 2 \\
\hline $12(6)$ & *2 & 1 & - & - & - & - & - & - & - & - & - & - & - & - \\
\hline $13(3)$ & $* 1$ & - & - & - & - & - & 1 & 2 & 3 & 2 & 2 & 1 & 1 & - \\
\hline $14(2)$ & 1 & 0 & 1 & 0 & - & - & - & - & - & - & 0 & 0 & 2 & 0 \\
\hline $15(1)$ & 1 & 2 & 1 & 1 & 1 & 2 & - & 2 & 2 & 0 & 0 & ${ }^{*} 0$ & 0 & 2 \\
\hline $16(2)$ & 2 & $* 1$ & 2 & 1 & 1 & 2 & 2 & 2 & 2 & 2 & 2 & 1 & 1 & 1 \\
\hline $18(1)$ & & & 2 & 1 & - & 1 & 1 & 0 & 1 & 2 & 1 & 0 & 2 & 1 \\
\hline 19 (1) & & & - & - & - & - & - & - & - & - & - & - & - & - \\
\hline 21 (2) & & & - & $\because$ & - & - & - & - & - & - & - & - & - & - \\
\hline $22(2)$ & & & - & $*$ & - & - & - & - & - & - & - & - & - & - \\
\hline $23(3)$ & & & & - & - & - & - & 0 & - & 0 & - & - & 0 & 0 \\
\hline $24(3)$ & & & & & & & & $* 1$ & 2 & 2 & 2 & 2 & 2 & 0 \\
\hline 25 (1) & & & & & & & & - & - & - & - & . & . & *- \\
\hline $26(1)$ & & & & & & & & & 1 & 0 & 1 & 3 & 2 & 3 \\
\hline $27(2)$ & & & & & & & & & & 2 & 2 & 0 & 2 & 2 \\
\hline 28 (1) & & & & & & & & & & 1 & 1 & $x$ & X & $x$ \\
\hline $17(1)$ & & & & & & & & & & & 2 & 0 & 0 & 2 \\
\hline $29(1)$ & & & & & & & & & & & - & - & - & - \\
\hline 31 (1) & & & & & & & & & & & - & 2 & 1 & 2 \\
\hline $20(2)$ & & & & & & & & & & & & 0 & 0 & 0 \\
\hline $30(1)$ & & & & & & & & & & & & & & - \\
\hline
\end{tabular}


Table 2. Summary of nesting success by year from the pine region of southcentral Oregon.

\begin{tabular}{|c|c|c|c|c|c|c|c|c|c|c|c|c|c|c|}
\hline & \multicolumn{14}{|c|}{ Year } \\
\hline & 1971 & 72 & 73 & 74 & 75 & 76 & 77 & 78 & 79 & 80 & 81 & 82 & 83 & 84 \\
\hline Number of sites & 16 & 16 & 20 & 21 & 21 & 21 & 21 & 23 & 24 & 26 & 29 & 30 & 30 & 31 \\
\hline Number of nests & 27 & 27 & 37 & 37 & 37 & 38 & 39 & 38 & 43 & 51 & 60 & 60 & 66 & 69 \\
\hline $\begin{array}{l}\text { Number of sites with } \\
\text { prior logging history }\end{array}$ & 10 & 11 & 12 & 15 & 15 & 15 & 15 & 16 & 16 & 16 & 17 & 18 & 18 & 19 \\
\hline $\begin{array}{l}\text { Number of sites with } \\
\text { no logging history } \\
\text { Percent of logged }\end{array}$ & 6 & 5 & 8 & 6 & 6 & 6 & 6 & 7 & 8 & 10 & 12 & 12 & 12 & 13 \\
\hline $\begin{array}{l}\text { sites occupied } \\
\text { Percent of unlogged }\end{array}$ & 60 & 45 & 33 & 60 & 20 & 33 & 33 & 38 & 56 & 50 & 47 & 61 & 61 & 58 \\
\hline $\begin{array}{l}\text { sites occupied } \\
\text { Number of sites }\end{array}$ & 83 & 40 & 50 & 67 & 17 & 33 & 33 & 57 & 50 & 60 & 58 & 64 & 73 & 73 \\
\hline $\begin{array}{l}\text { occupied } \\
\text { Number of sites }\end{array}$ & 11 & 7 & 8 & 13 & 4 & 9 & 7 & 10 & 13 & 15 & 16 & 18 & 19 & 19 \\
\hline $\begin{array}{l}\text { successful } \\
\text { Number of eaglets }\end{array}$ & 9 & 5 & 7 & 6 & 3 & 5 & 5 & 7 & 10 & 8 & 10 & 9 & 13 & 10 \\
\hline $\begin{array}{l}\text { fledged } \\
\text { Eaglets fledged per }\end{array}$ & 12 & 6 & 10 & 8 & 3 & 7 & 6 & 11 & 16 & 14 & 16 & 14 & 21 & 17 \\
\hline occupied site & 1.09 & .86 & 1.25 & .62 & .75 & .78 & .86 & 1.10 & 1.23 & .93 & 1.00 & .78 & 1.11 & .89 \\
\hline
\end{tabular}

Table 3. Nesting success at eagle nesting sites in the fir region of coastal Oregon and Washington. Logging activity is indicated by ${ }^{*} .0$ is a nest failure; 1 or 2 is a nesting success and the number of eaglets fledged; - is a symbol for inactive classification.

\begin{tabular}{|c|c|c|c|c|c|c|c|c|}
\hline \multirow{2}{*}{$\begin{array}{c}\text { Nesting site } \\
\text { (number of nests) }\end{array}$} & \multicolumn{8}{|c|}{ Year } \\
\hline & 1977 & 78 & 79 & 80 & 81 & 82 & 83 & 84 \\
\hline CC (2) & - & $\cdot 2$ & 2 & 2 & 1 & 1 & 1 & 2 \\
\hline CR (1) & $*$ & - & - & - & - & - & - & 1 \\
\hline CK (2) & $*$ & 1 & 1 & 1 & 2 & ${ }^{\star} 0$ & 2 & 2 \\
\hline GR (1) & $*$ & - & - & - & - & - & - & - \\
\hline $\mathrm{HP}$ (2) & $* 1$ & 0 & 2 & 1 & 0 & 1 & 2 & 1 \\
\hline MR (1) & *2 & 2 & 0 & 0 & 0 & 0 & 1 & 0 \\
\hline NR (2) & & 2 & 0 & $* 1$ & 0 & 0 & - & - \\
\hline SL (4) & & & & 1 & 0 & 0 & 0 & 2 \\
\hline TS (2) & & & & $*$ & - & - & - & - \\
\hline CP (2) & & & & & ${ }^{*} 0$ & ${ }^{*} 0$ & 0 & 0 \\
\hline NR (1) & & & & & & 1 & 1 & 0 \\
\hline $\mathrm{KR}$ (1) & & & & & & & *- & - \\
\hline SB (2) & & & & & & & 0 & 1 \\
\hline
\end{tabular}

trees also were retained about nest trees. By the mid 1970s, vegetative buffers were delineated by natural characteristics of the area to provide some isolation and protection to nest trees.

The eagle management program currently practised on Weyerhaeuser Company land consists of assessing the characteristics of each nesting area and preparing a management plan outlining the boundaries of protective zones and the timing of forest management activities. The management plan establishes boundaries specific to each site based on terrain, land use, adjacent forest stand conditions and silvicultural objectives. Reference is made to published management guidelines, but actual decisions are based on the characteristics of the land and the presence of the birds. The site-specific management plan is reviewed with state forestry and wildlife agencies and is implemented upon their concurrence.

\section{Results and Discussion}

Currently, 90 bald eagle nests located within 44 nesting sites are known within company ownership: 31 sites (69 nests) occur in the pine - mixed conifer forest type in Oregon (Table 2), and 13 sites (21 nests) occur in the Douglas-fir type of Oregon and Washington (Table 4). Twelve additional nests have been identified since 1971 , but no longer exist due to loss by wind, lightning or trespass firewood cutting. These nests and their nesting history are included in Tables 1-4. The apparent increase in the number of nests and nesting sites, from 16 sites ( 27 nests) in 1971 to 31 sites ( 69 nests) in 1984 for the pine region (Table 2 ) and 6 sites ( 7 nests) to 13 sites (21 nests) for the fir region (Table 4), reflects more intensive search effort and not an increase in the nesting eagle population, which appears to have remained stable during this period. As additional nests are located, adjustments are made in the boundaries of nesting sites to incorporate the new information. Because it is likely that certain "new" nests may have existed prior to their discovery, the historical productivity data presented are thought to be conservative.

The mean ( \pm SE) percent of occupied sites that successfully fledged birds is $66( \pm 3) \%$ in the pine region and $64( \pm 8) \%$ in the fir region. Average nesting success is $0.95( \pm 0.05)$ and $0.95( \pm 0.14)$ eaglets per occupied site in the pine and fir regions, respectively (Tables 2 and 4 ). Annual variation in nesting success ranges from 0.62 to 1.25 for 14 years in the pine region and 0.38 to 1.50 for the past 8 years in the fir region. This nesting success rate exceeds the population maintenance level, based on conclusions of Sprunt et al. (1973) who stated that to have a stable population at least $50 \%$ of occupied sites should be successful with a production rate exceeding 0.70 eaglets fledged per occupied site.

All known forest management activities conducted within $1 \mathrm{~km}$ of any nest within a nesting site are documented. Clearcutting, selective harvest, timber salvage, site preparation, planting, herbicide applications, and precommercial thinning activities are included. Although some sites have experienced no recent activities, most have received some level of silvicultural treatment in the past, with several sites having been subjected to a number of activities through time. Tables 1 and 3 identify those sites where some logging occurred: $61 \%$ of the sites in the pine region and $77 \%$ in the fir region have had some logging activity to date. Only logging is emphasized because this activity causes the greatest habitat change and its influence, if any, on nesting success should be most readily apparent. The mean ( \pm SE) percent of logged and unlogged sites classified as active in the pine region was $47( \pm 4) \%$ and $54( \pm 5) \%$ respectively; no significant difference $(p \leq 0.05$, t-test) exists between the two (Table 2). For the fir region 60 $( \pm 4) \%$ of logged sites were active. Due to insufficient sample size, no test of differences between logged and unlogged sites was made (Table 4).

Selected case histories are presented below to display the range of forest management activities occurring in nesting 
Table 4. Summary of nesting success by year from the fir region of western Oregon and Washington.

\begin{tabular}{|c|c|c|c|c|c|c|c|c|}
\hline & \multicolumn{8}{|c|}{ Year } \\
\hline & 1977 & 78 & 79 & 80 & 81 & 82 & 83 & 84 \\
\hline Number of sites & 6 & 7 & 7 & 10 & 10 & 11 & 13 & 13 \\
\hline Number of nests & 7 & 8 & 9 & 16 & 17 & 17 & 19 & 21 \\
\hline Number of sites with prior logging history & 5 & 6 & 6 & 8 & 9 & 9 & 10 & 10 \\
\hline Number of sites with no logging history & 1 & 1 & 1 & 2 & 1 & 2 & 3 & 3 \\
\hline Percent of logged sites occupied & 40 & 67 & 67 & 63 & 67 & 67 & 50 & 60 \\
\hline Percent of unlogged sites occupied & 0 & 100 & 100 & 100 & 100 & 100 & 100 & 100 \\
\hline Number of sites occupied & 2 & 5 & 5 & 7 & 7 & 8 & 8 & 8 \\
\hline Number of sites successful & 2 & 4 & 3 & 5 & 2 & 3 & 5 & 6 \\
\hline Number eaglets fledged & 3 & 7 & 5 & 6 & 3 & 3 & 7 & 9 \\
\hline Eaglets fledged per occupied sites & 1.50 & 1.40 & 1.00 & 86 & .43 & .38 & .86 & 1.13 \\
\hline
\end{tabular}

sites and the patterns of nesting success observed. Included are examples where nesting occurred annually, as well as irregularly, both with or without logging in adjacent areas, to shed light on the extent of the variation that occurs.

Site 1. This site has a history of nine nest trees, four of which were located in late 1970 when the immediate area around these nests was selectively logged. One of these nests (A) was used in 1971, 1973-1980,1982, and 1983. The other three nests were inactive during this period. Nest $(A)$ was classified as a failure in 1971, inactive in 1972, productive in 1973-75, a failure in 1976, and productive in 1977-80. This nest tree was killed by pine beetle attack in 1979. The fifth nest (E) was productive in 1981 and was found in an unlogged area of the nesting site between the food source and the first four nests. This nest tree (E) blew down during the winter of 1981 Nest tree (A), which is now a snag as a result of pine beetle damage, was again successful in 1982 and 1983. Four additional nests were found in the unlogged portion of the site, one in 1982 and three in 1983; one of these latter nests was productive in 1984. Although the possibility exists that this site is now used by a different pair of birds favoring a different part of the site, the locations of all nine nests in close proximity to the same apparent feeding area suggest a single nesting site used continually by one pair of birds.

Site 16. Two nest trees, one of which apparently came down in 1976, occurred in an area that was selectively harvested and precommercially thinned extensively in late 1971. The same nest has been productive each year from 1971 through 1984

Site 12. This site contains six nest trees, two nests were located in late 1970 when the area was being selectively logged and four others were located in 1980 in an unlogged cliff area. One of the nests found in the area being harvested was productive in the first two years(1971 and 1972) following logging, but the site in total has been inactive since 1973

Site 9. This site contains five nest trees; three were located in late 1970, one of which (A) was productive in 1971, another (B) productive in 1973 and 1974 , and the third (C) productive in 1976 through 1979. This latter nest (C) failed in 1980 prior to the time when the area around these three nests was selectively logged. A fourth nest (D), first found in 1973 and located in an unlogged area of the site, was a failure in 1981, but productive in 1982 through 1984 . The fifth nest $(E)$ was found in 1983 and, also located in the unlogged portion of the site, has been classified as inactive in both 1983 and 1984. The site, then, was productive in 1971, 1973-74, 1976-79, and 1982-84 and a failure in 1980 and 1981. Since the logging occurred, the nests located in the logged area (A, B, and C) have been inactive with the productive nest $(D)$ located in the unlogged portion of the site. Through frequent observations of the pair of eagles using the area, R. Frenzel (pers. comm.) noted the possibility of a change of mates during 1980 which may have contributed to the change in nest use. Also, heavy public fishing use offshore from the logged area of the first three nests ( $A, B$, and $C$ ) may have had additional influence on nest use.

Site CP. Two nest trees were located in late 1979 during road construction activities. Clearcutting was conducted near each nest in late 1980 and again in 1981. The site has failed each year since 1980 , with both nests being used in different years.

Site SL. Four nests, located in residual trees which were left when the area was clearcut in the 1940 s, occur in an area that has had little recent management activity. These nests have been known since the mid-1970s and productivity observations have been made since 1980. Three of the four nests have been used; the site was classified as a failure for 1981 83 and as productive in 1980 and 1984 .

From these case histories and all other sites that we have observed, it appears that nesting successes and failures occur whether or not forest management activities are conducted. Although some questions on the status of particular nests may be raised, management-caused effects on nesting success are not apparent. Possible nesting disturbances from other causes have occurred and include shooting, firewood cutting, recreational use, road and aircraft traffic, overzealous photographers, banding of eaglets, and volcanic eruptions. The influences of weather, particularly during early spring storms, and of food supplies on nesting success also are not well understood, but appear important.

\section{Conclusions}

Our observations of continued eagle nesting on actively managed forest land indicate these activities are compatible when forest management practices are planned and conducted with care during the noncritical period of eagle occupancy. Our understanding of why nesting eagles do or do not return to an individual nest after logging has occurred in the vicinity is incomplete; however, observations indicate nesting success is highly variable even in the absence of forest management. We believe it has been demonstrated that with proper planning and execution, both eagles and forest products can be produced on the same areas. Management of eagle habitat on Weyerhaeuser forest lands continues to be approached through control of the nature and timing of various activities. We believe management guidelines should be sufficiently flexible to accommodate the specific characteristics and conditions around each nest tree and should not exclude active forest management. Through a cooperative 
approach to management, the benefits to both forest management and eagle habitat can be realized. An important consideration is that attention should be given to the management of the entire nesting site rather than directed only at individual existing nesting trees. Manipulation of tree diameter, height, density, and form through silviculture is a means to enhance existing nesting areas or provide for new ones over time within a nesting site. Forest stand manipulation could provide essential nesting habitat by providing prominent trees with the physical characteristics and strength required to support a nest.

\section{Acknowledgements}

Appreciation is extended to numerous individuals who have assisted with support, observations, and interest in the completion of this report. B.Z. Agrons provided enthusiastic initial support for this work. A.M. Bruce, F.B. Isaacs, R.G. Anthony, J.P. Hoppe, C.A. Leslie, and V.H. Ray made nesting observations and stimulated much thought and discussion on land management influences. Support from regional forestry, logging, engineering, and corporate aviation staff is appreciated for assistance with surveys and carrying through operating plans. A.M. Bruce, J.A. Rochelle, and W.H. Lawrence provided critical reviews of the manuscript.

\section{References}

Anthony, R.G., R.L. Knight, G.T. Allen, B.R. McClelland and J.I. Hodges. 1982. Habitat use by nesting and roosting bald eagles in the Pacific Northwest. Trans. North Am. Wildl. and Natur. Resour. Conf. 47: 332-342.

Chrest, H.R. 1964. Review of literature: the bald eagle. M.S. Thesis, Colo. State Univ., Fort Collins. $121 \mathrm{p}$.

Corr, P.O. 1974. Bald eagle (Haliaeetus leucocephalus alascanus) nesting related to forestry in southeastern Alaska. M.S. Thesis, Univ. Alaska, College. 144 p.

Fraser, J.D. 1981. The breeding biology and status of the bald eagle on the Chippewa National Forest. Ph.D. Thesis, Univ. Minnesota, Minneapolis. 236 p.

Grubb, T.G. 1980. An artificial bald eagle nest structure. USDA For. Serv. Res. Note RM-383. Rocky Mountain For, and Range Exper. Sta. $4 \mathrm{p}$.

Herrick, F.H. 1924. The daily life of the American eagle: late phase. Auk 41(3): 389-422, 517-541.

Lehman, R.N. 1980. A survey of selected habitat features of 95 bald eagle nest sites in California. Calif. Dep. Fish and Game. Wildı. Manage. Branch Admin. Rep. 79-1.23 p.

Lincer, J.L., W.S. Clark and M.N. LeFranc, Jr. 1979. Working bibliography of the bald eagle. Nat. Wildl. Fed. Scientific and Technical Series No. 2. Raptor Inf. Center, Washington, D.C. 244 p.

Mathisen, J.E. 1968. Effects of human disturbance on nesting of bald eagles. J. Wildl. Manage. 32(1): 1-6.

Mattsson, J.P. and A.H. Grewe, Jr. 1976. Bald eagle nesting in the Superior National Forest. USDA For. Serv. Res. Note NC-198. $2 \mathrm{p}$.

McEwan, L.C. and D.H. Hirth. 1979. Southern bald eagle productivity and nest site selection. J. Wildl. Manage. 43(3): 585-594.

Newman, J.R., W.H. Brennan and L.M. Smith. 1977. Twelve-year changes in nesting patterns of bald eagles (Haliaeetus lencocephalus) on San Juan Island, Washington. Murrelet 58(2): 37-39.

Postupalsky. S. 1974. Raptor reproductive success: some problems with methods, criteria and terminology. Pages 21-31, in F.N. Hamerstrom, Jr., B.E. Harrell and R.R. Olendorff, eds. Management of raptors. Proc. Conf. Raptor Conserv. Tech., Raptor Res. Rep. No. 2.

Snow, C. 1973. Southern bald eagle (Haliaeetus leucocephalus leucocephalus) and northern bald eagle (Haliaeetus leucocephalus alascanus). Habitat management series for endangered species. Rep. 5. Bur. Land Manage. Tech. Note 171. $58 \mathrm{p}$.

Sprunt, A., IV, W.B. Robertson, Jr., S. Postupalsky, R.J. Hensel, C.E. Knoder and F.J. Ligas. 1973. Comparative productivity of six bald eagle populations. Trans. North Am. Wildl. and Nat. Resour. Conf. 38: 96-106.

Stocek, R.F. and P.A. Pearce. 1981. Status and breeding success of New Brunswick bald eagles. Can. Field Nat. 95(4): 428-433.

Swensen, J.E. 1975. Ecology of the bald eagle and osprey in Yellowstone National Park. M.S. Thesis. Montana State Univ., Bozeman. $146 p$

USDI Fish and Wildlife Service. 1981. Bald eagle management guidelines for Oregon and Washington. Portland, Oregon. $10 \mathrm{p}$

USDI Fish and Wildlife Service. Management guidelines for the bald eagle in the Southeastern Region. Atlanta, Ga. 11 p.

USDI Fish and Wildlife Service. 1983. Northern States bald eagle recovery plan. Denver, Colo. $117 \mathrm{p}$.

Whitfield, D.W.A., J.M. Gerrard, W.J. Maher and D.W. Davis. 1974. Bald eagle nesting habitat, density and reproduction in central Saskatchewan and Manitoba. Can. Field Nat. 88: 399-407.

Young, L.S. 1980. A quantitative evaluation of human disturbance impacts on breeding ecology of bald eagles in the San Juan Islands, Washington. Wash. Dep. of Game Rep. Olympia, 38 p. 